\title{
ROZWIJANIE KOMPETENCJI POZYSKIWANIA INFORMACJI W DYDAKTYCE PRZEKŁADU NA PRZYKŁADZIE PRACY ZE SŁOWNIKAMI I TEKSTAMI PARALELNYMI
}

Zarys treści: Kompetencja zdobywania informacji jest jedną z sześciu zawodowych kompetencji tłumacza opracowanych przez grupę ekspertów powołanych przez Dyrekcję Generalną ds. Tłumaczeń Pisemnych (DGT) przy Komisji Europejskiej w ramach projektu utworzenia europejskiej sieci European Master's in Translation (EMT). W dydaktyce przekładu rozwijaniu tej ważnej umiejętności poświęca się niewiele uwagi lub też wręcz pomija, traktując ją jako umiejętność oczywistą, niewymagającą kształcenia. Praktyka pokazuje jednak, że wobec natłoku informacji i wymogu efektywnego zarządzania czasem zdolność sprawnego wyszukiwania informacji i krytycznego podejścia do różnych źródeł informacji powinna stanowić nieodzowny element kształcenia profesjonalnych tłumaczy. W niniejszym artykule zostaną zaprezentowane przykładowe metody pracy ze słownikami i tekstami paralelnymi rozwijające tę kompetencję.

\section{Wstęp}

Yompetencja pozyskiwania informacji stanowi jeden $\mathrm{z}$ aspektów kompetenMcji tłumaczeniowej, która jest czymś więcej niż tylko sumą kompetencji językowych co najmniej dwóch języków, tj. języka źródłowego i docelowego (por. Göpferich 2009: 75; Koller 2011: 13). W teorii tłumaczenia zagadnienie kompetencji tłumaczeniowej jest obecne od lat 70. ubiegłego wieku i w tym czasie ukazało się wiele publikacji, które pozwalają prześledzić ewolucję poglądów badaczy na ten temat (por. Kościałkowska-Okońska 2007: 217-223, Piotrowska 2007: 118-130). Wydaje się, że najistotniejszą konsekwencją tego 
rozwoju jest konkluzja, że kompetencja tłumaczeniowa nie jest jedynie zdolnością wrodzoną, talentem, lecz że można i należy ją kształcić. Dało to początek wymianie myśli nad problemem rozwijania kompetencji tłumaczeniowej i jej komponentów w ramach dydaktyki przekładu.

Do refleksji na temat kształtowania kompetencji tłumaczeniowej przyczyniła się z pewnością globalizacja, stale rosnący popyt na wysokiej jakości produkty i usługi ( $w$ tym przypadku tłumaczenia) oraz związane z tym dążenie do zapewnienia jakości w drodze standaryzacji. W 2006 r. Europejski Komitet Normalizacyjny wydał europejską normę EN $15038^{1}$, pierwszą normę jakościową wyznaczającą standardy i procedury dla świadczenia najwyższej jakości usług w zakresie przekładu pisemnego. Norma EN 15038 reguluje nie tylko sam proces tłumaczenia, lecz także inne związane z nim aspekty, określając wymagania w zakresie zasobów ludzkich, zasobów technicznych, systemu zarządzania jakością, zarządzania realizacją zleceń, relacji z klientem, procedur obowiązujących w świadczeniu usług tłumaczeniowych oraz w zakresie monitorowania i kontroli procesu tłumaczenia. Tak duży obszar regulacji wyraźnie pokazuje, że obecnie praca tłumacza daleko wykracza poza proces samego przekładu, ponieważ obejmuje również zadania, które nie mieszczą się w tradycyjnym rozumieniu tłumaczenia. Chodzi tutaj np. o lokalizację, redagowanie tekstów, tłumaczenie napisów do filmów, przetwarzanie tekstów na potrzeby tłumaczenia maszynowego (pre-editing) i opracowywanie tłumaczeń maszynowych (post-editing) czy też zarządzanie projektami (por. Europejskie studia drugiego stopnia $w$ dziedzinie tłumaczeń, Kautz 2002: 18). Prawdopodobnie $\mathrm{z}$ tego względu norma posługuje się określeniem o szerszym zakresie znaczeniowym niż „tłumacz”, a mianowicie „dostawca usług tłumaczeniowych”.

Norma EN 15038 precyzuje również minimum kompetencji, jakie powinien posiadać profesjonalny tłumacz. Kompetencje te są wymienione w obszarze wymogów dotyczących zasobów ludzkich. Są to: kompetencja tłumaczeniowa, czyli zdolność wykonania przekładu na odpowiednim poziomie, kompetencja językowa i tekstowa w języku źródłowym i docelowym, umiejętność pozyskiwania informacji i ich przetwarzania, kompetencja kulturowa oraz kompetencja techniczna, czyli umiejętność obsługi narzędzi potrzebnych do realizacji projektu tłumaczeniowego, np. komputera i oprogramowania (por. Abstract of the European Quality Standard for Translation Services). Tak wysoki poziom kompetencji, jakiego od tłumaczy oczekuje współczesny rynek pracy, wymaga stworzenia odpowiedniego programu nauczania, i to na szczeblu ponadnarodowym.

${ }^{1}$ Norma ta zastąpiła w Niemczech normę DIN 2345, a w Austrii normę ÖNORM D1200. 
Potrzebę kształcenia profesjonalnych tłumaczy w wymiarze europejskim dostrzegła Dyrekcja Generalna ds. Tłumaczeń Pisemnych Komisji Europejskiej, która w 2006 r. w ramach projektu utworzenia europejskiej sieci European Master's in Translation (EMT) powołała grupę ekspertów z dziedziny tłumaczeń pisemnych i powierzyła im zadanie opracowania zestawu kompetencji zawodowych, które powinni nabyć absolwenci studiów tłumaczeniowych EMT (por. Co brzmi w trzcinie 2011: 10-11). W ten sposób powstała lista obejmująca sześć umiejętności, tj. umiejętność świadczenia usług w zakresie tłumaczeń pisemnych (łącznie z zarządzaniem relacjami z klientami), umiejętności językowe i międzykulturowe (biegła znajomość języka źródłowego i docelowego, umiejętność streszczania tekstów oraz zdolność rozumienia informacji zawierających aluzje kulturowe), umiejętność wyszukiwania informacji (zdolność wyszukiwania informacji i krytyczne podejście do różnych źródeł informacji), umiejętności techniczne, zwłaszcza w korzystaniu $\mathrm{z}$ pamięci tłumaczeniowych i w zarządzaniu terminologią, umiejętności tematyczne (wiedza w dziedzinach specjalistycznych i jej zastosowanie w praktyce profesjonalnego tłumaczenia) (por. European Master's in Translation).

Także w teorii przekładu prowadzono badania nad komponentami kompetencji tłumaczeniowej, np. Risku 1998; PACTE 2000, 2002, 2003, 2005; Kautz 2002; Göpferich 2008, 2009 (por. Kautz 2002 19-26; Göpferich 2008: 151-157; Göpferich 2009: 80-86). Mimo iż badacze prezentują różne poglądy na temat tego, jakie kompetencje cząstkowe tworzą kompetencję tłumaczeniową i w jaki sposób należy je rozgraniczać, to jednak wydaje się, że trzy spośród nich nie budzą wątpliwości, a mianowicie kompetencja komunikacyjna w języku wyjściowym i docelowym, kompetencja merytoryczna i specjalistyczna oraz kompetencja korzystania z konwencjonalnych i elektronicznych narzędzi do pozyskiwania informacji (por. Göpferich 2008: 148).

Z zaprezentowanych refleksji wstępnych wynika jednoznacznie, że kompetencja pozyskiwania informacji należy do bardzo istotnych umiejętności, jakie powinien posiadać współczesny tłumacz. Jak podkreśla się w literaturze przedmiotu, wyszukiwanie informacji zajmuje średnio trzy czwarte czasu pracy tłumacza (por. Kautz 2002: 89). W dydaktyce przekładu rozwijaniu tej umiejętności poświęca się jednak niewiele uwagi lub też wręcz pomija, traktując ją jako umiejętność oczywistą, niewymagającą kształcenia. Praktyka pokazuje natomiast, że w dobie społeczeństwa informacyjnego, „gdzie zarządzanie informacją, jej jakość, szybkość przepływu są zasadniczymi czynnikami konkurencyjności zarówno w przemyśle, jak i w usługach, a stopień rozwoju wymaga stosowania nowych technik gromadzenia, przetwarzania, przekazywania i użytkowania informacji” (ePolska 2001: 67-68), umiejętność 
ta jest wręcz nieodzowna. Tak więc wobec natłoku informacji i wymogu efektywnego zarządzania czasem zdolność efektywnego wyszukiwania informacji i krytycznego podejścia do różnych źródeł informacji powinna stanowić niezbędny element kształcenia profesjonalnych tłumaczy.

\section{Kompetencja pozyskiwania informacji}

Kompetencja zdobywania informacji nie wiąże się - jak mogłoby się pozornie wydawać - tylko z samym procesem tłumaczenia. Według Hansa G. Höniga umiejętność ta jest nieodłącznym elementem także fazy rozumienia tekstu wyjściowego (Hönig 2006: 160, 162). Dotyczy to przede wszystkim tekstów o tematyce ogólnej, gdzie krytyczne podejście do rozumienia tekstu może ustąpić miejsca bezrefleksyjnym, automatycznym skojarzeniom związanym z zasobami wiedzy zgromadzonej w głowie tłumacza, a w konsekwencji może prowadzić do błędnego tłumaczenia. Tłumacz zakłada bowiem, że zna temat i w tym zakresie nie ma braków w wiedzy (por. Hönig 2006: 161). Aby zatem uniknąć błędnego zrozumienia tekstu w wyniku bezkrytycznego podejścia i w następstwie błędnego tłumaczenia, przed przystąpieniem do fazy samego przekładu tłumacz powinien zapoznać się z tematyką tekstu wyjściowego na podstawie innych dostępnych materiałów. Ten etap pracy tłumacza doskonale można zilustrować refleksją Umberto Eco, jaką zapisał on w czasie pracy nad powieścią Imię róży:

Odkryłem mianowicie, że w okresie początkowym nic powieści po słowach. Pisanie powieści to przedsięwzięcie kosmologiczne [...] (nie obejdzie się bez wybrania sobie jakiegoś wzorca - powiedział Woody Allen). [...] Mam na myśli to, że jeśli chce się zasiąść do pisania, trzeba sobie najpierw zbudować świat możliwie najdokładniej urządzony, aż do ostatnich szczegółów. Jeślibym wyobraził sobie rzekę, dwa brzegi i na brzegu lewym umieścił rybaka, jeślibym ponadto wyposażył tego rybaka w charakter wybuchowy, przypisał mu spory rejestr występków, mógłbym przystąpić do pisania, przekładając na słowa to, co musiałoby nastąpić. [...] Pierwszy rok pracy nad powieścią poświeciłem więc budowaniu świata (Eco 1984: 437-438).

Odnosząc ten obraz do procesu tłumaczenia, można powiedzieć, że chodzi o świadome i krytyczne mentalne skonstruowanie scen mające na celu dokonanie oceny posiadanej wiedzy, zdiagnozowanie braków i jej uzupełnienie, wykorzystując dobrze rozwiniętą kompetencję pozyskiwania informacji (por. Hönig 2006: 163). 
Podsumowując związek umiejętności zdobywania informacji i rozumienia, należy stwierdzić, że profesjonalny tłumacz musi być w stanie zweryfikować posiadaną przez siebie wiedzę $\mathrm{w}$ danym zakresie, uporządkować ją i w razie potrzeby uzupełnić.

Mogłoby się wydawać, że doświadczony profesjonalny tłumacz znacznie rzadziej korzysta $z$ dodatkowych narzędzi pracy, jak np. słowniki, publikacje specjalistyczne, i znacznie rzadziej konsultuje się ze specjalistami z danej dziedziny. Nic bardziej mylnego, ponieważ zakres tematyczny zlecanych tłumaczeń jest dziś tak szeroki, że tłumacz musi stale i systematycznie aktualizować i poszerzać zasoby swojej wiedzy, aby w określonym terminie mógł wykonać wysokiej jakości usługę. Dlatego też Hans P. Krings zakłada, że tłumacze zawodowi znacznie częściej sięgają do różnego rodzaju mediów niż osoby uczące się języka, które z reguły ograniczają się do korzystania ze słowników dwujęzycznych (por. Krings za Risku 1998: 167). Tłumacz nie musi wiedzieć wszystkiego, ale musi wiedzieć, gdzie i w jaki sposób szukać pomocy, aby efektywnie wykorzystać czas, który ma do dyspozycji na wykonanie zadania tłumaczeniowego. Jest to o tyle istotne, że tłumacze najczęściej pracują pod presją czasu (por. Kautz 2002: 89).

Biorąc pod uwagę dotychczasowe rozważania, można zaproponować następującą definicję kompetencji pozyskiwania informacji: jest to wiedza i zdolność wyszukiwania informacji przy użyciu narzędzi translatorskich oraz umiejętność krytycznego podejścia do różnych źródeł informacji (por. Göpferig 2008: 149, Europejskie studia drugiego stopnia $w$ dziedzinie tłumaczeń). Narzędzia pracy tłumacza to „zewnętrzne reprezentacje zasobów wiedzy, do których sięga tłumacz, aby zwiększyć własne zasoby wiedzy" (Nord 2002: 158, tł. KS). Za Brittą Nord (2002: 6-7) narzędzia pracy tłumacza można podzielić na narzędzia prymarne i sekundarne. Do narzędzi prymarnych zalicza się przede wszystkim drukowane i elektroniczne kompendia wiedzy oraz drukowane i elektroniczne teksty pomocnicze. Kompendia wiedzy to atlasy, podręczniki, kroniki, dzieła leksykograficzne, czyli słowniki i encyklopedie, oraz dokumentacja własna tłumacza. Teksty pomocnicze można podzielić na tzw. podtłumaczenia (przetłumaczone fragmenty tekstu wyjściowego, które są w pełni zgodne $\mathrm{z}$ fragmentami tekstów przetłumaczonych już wcześniej), uzupełniające teksty informacyjne (teksty oryginalne i tłumaczenia zawierające wiedzę merytoryczną, np. podręczniki czy informatory) i teksty paralelne (por. Nord 2002: 159-160). Natomiast narzędzia sekundarne to np. bazy terminologiczne oraz inne bazy danych, wyszukiwarki internetowe, korpusy, systemy zarządzania terminologią, oprogramowanie służące do tłumaczenia wspomaganego komputerowo, tzw. narzędzia CAT 
(por. Nord 2002: 7). Klasyfikacja narzędzi translatorskich została przytoczona w celu określenia miejsca słowników i tekstów paralelnych wśród pomocy, jakie mają do dyspozycji tłumacze. Mimo ogromnego postępu technicznego, który dokonał się od końca XX w. w usługach tłumaczeniowych, to właśnie słowniki i teksty paralelne - dzisiaj coraz częściej w wersji elektronicznej stanowią nadal podstawowe wyposażenie warsztatu tłumacza prowadzącego własną działalność. Dzieje się tak z pewnością ze względu na wysokie koszty zakupu narzędzi CAT oraz konieczność szkolenia w zakresie ich obsługi, co wiąże się również z niemałym wydatkiem.

W dalszej części artykułu zostaną zaprezentowane wybrane ćwiczenia kształcące umiejętność pozyskiwania informacji ze słowników i tekstów paralelnych, które są poprzedzone istotnymi uwagami dotyczącymi aspektów teoretycznych.

\section{Słowniki}

Jedną z podstawowych klasyfikacji słowników jest podział na słowniki jedno- i dwu-, względnie wielojęzyczne. Słowniki jedno-, dwu- i wielojęzyczne z reguły mają podobną makrostrukturę. Najczęściej charakteryzują się one alfabetycznym układem artykułów hasłowych. Za artykułem hasłowym znajdują się takie informacje jak np. rodzaj części mowy, pochodzenie i wymowa (por. Snell-Hornby 2006: 181). Najistotniejszą różnicą jest natomiast rodzaj zawartej w nich informacji, ponieważ słownik jednojęzyczny podaje jedną lub wiele definicji znaczeniowych sformułowanych w języku, którego elementy są przedmiotem opisu, a słownik dwu- lub wielojęzyczny zawiera jeden lub wiele odpowiedników w innym bądź w innych językach.

Adepci sztuki przekładu preferują słowniki dwujęzyczne, gdyż są bardzo często mylnie przekonani, że słownik stanowi pełne opracowanie wiedzy o języku i jako taki podaje gotowe rozwiązanie, czyli ekwiwalenty tłumaczeniowe jednostek leksykalnych występujących w tekście wyjściowym (por. Hejwowski 2004: 29, 34). Takie podejście świadczy o tym, że traktują oni proces tłumaczenia jako operację transkodowania: „Wystarczy wziąć taką gotową cegiełkę ze słownika dwujęzycznego i wetknąć ją w odpowiednie miejsce tekstu docelowego" (Hejwowski 2004: 29). Studenci i nowicjusze unikają słowników jednojęzycznych, skarżąc się, że nie rozumieją podanych definicji i/lub przykładów użycia jednostek leksykalnych w konkretnych kontekstach, co wynika zapewne $\mathrm{z}$ niedostatecznych kompetencji językowych i z braku wiary we własne umiejętności (por. Kautz 2002: 93). W dydaktyce 
przekładu, zwłaszcza na zajęciach rozwijających kompetencję pozyskiwania informacji, należy uświadomić uczącym się, że słowniki dwujęzyczne mogą jedynie wskazywać drogę do rozwiązania i pobudzić kreatywność tłumacza w poszukiwaniu właściwego ekwiwalentu (por. Stolze 1988: 58, Worbs 1997: 4) oraz że znaczenie potencjalnego odpowiednika należy sprawdzać w słowniku jednojęzycznym. Słownik jednojęzyczny stanowi bowiem nieodzowne narzędzie w ustalaniu znaczenia jednostek leksykalnych języka wyjściowego, gdyż podaje różne znaczenia i odcienie semantyczne wraz z przykładami użycia. Poza tym definicje znaczeniowe mają charakter parafrazy. Oznacza to, że znaczenia jednostek są opisane innymi słowami tego samego języka, dzięki czemu tłumacz bardzo często może znaleźć rozwiązanie, które będzie optymalne w danym kontekście, a którego nie notuje żaden słownik dwujęzyczny (por. Kautz 2002: 93). Z drugiej strony uczący powinni mieć świadomość, że także słownik jednojęzyczny nie jest idealnym narzędziem, ponieważ zdarza się, że informacje znaczeniowe są definicjami kołowymi (por. Worbs 1997: 2). W dydaktyce przekładu należy więc zwrócić uwagę na to, że tłumacz powinien korzystać również z innych źródeł informacji, np. z tekstów paralelnych.

Z punktu widzenia efektywności pracy trzeba pamiętać, że słowniki są narzędziem pracy tłumacza. Dlatego zarówno w słownikach jedno-, jak i dwujęzycznych warto dopisywać brakujące hasła, poszczególne wyrazy oraz dodatkowe informacje dotyczące poszczególnych haseł, a w słownikach dwujęzycznych dodatkowo brakujące ekwiwalenty (por. Dzierżanowska 1990: 64). Taką możliwość dają już także słowniki elektroniczne, np. Wielkie słowniki PWN wydane w $2010 \mathrm{r}$.

Reasumując rozważania teoretyczne, w kształceniu kompetencji wyszukiwania informacji w oparciu o słowniki nauczyciel powinien od samego początku zwrócić uwagę na ich ograniczone możliwości, powinien przeciwdziałać pokładaniu w nie bezgranicznej wiary, zawsze podkreślać decydującą rolę kontekstu, własnej wiedzy i sytuacji komunikacyjnej w poszukiwaniu ekwiwalentów i wskazać inne możliwości pozyskania informacji (por. Kautz 2002: 92).

A oto propozycje ćwiczeń pracy ze słownikami², które można wykorzystać do rozwijania zdolności efektywnego wyszukiwania informacji i krytycznego podejścia do słowników jako źródeł informacji.

2 Ćwiczenia pochodzą z publikacji Ulricha Kautza (2002: 216-228) oraz Materialien zu dem Themenbereich Arbeit mit dem Wörterbuch wydanych przez Ministerstwo Szkolnictwa i Edukacji Nadrenii Północnej-Westfalii. 
Ćwiczenie 1: Nauczyciel rozdaje studentom karty pracy z wybranym artykułem hasłowym ze słownika jednojęzycznego i prosi o podanie różnych rodzajów informacji, które można $\mathrm{z}$ niego wywnioskować, tj. samo hasło, informacje dotyczące gramatyki, etymologii, ewentualnie ortografii i wymowy, informacje znaczeniowe wraz z przykładami kontekstów użycia, kolokacje, frazeologizmy (załącznik 1). Cel ćwiczenia: uwrażliwienie studentów na strukturę artykułu hasłowego i stosowane zasady leksykograficzne.

Ćwiczenie 2: Nauczyciel rozdaje kartki z krótkim listem, w którym powtarza się jeden wyraz. Zadanie studentów polega na zastąpieniu w miarę możliwości powtarzającego się wyrazu odpowiednimi jednostkami leksykalnymi podanymi w słowniku jednojęzycznym (załącznik 2). Cel: zapoznanie studentów $\mathrm{z}$ definicją jako gatunkiem tekstu oraz użycie synonimów.

Ćwiczenie 3: Nauczyciel rozdaje karty pracy z kilkoma fragmentami tekstów, które zawierają polisemantyczny wyraz występujący w różnych kontekstach (załącznik 3) oraz ich tłumaczenia na język docelowy. Tłumaczenia zawierają luki w miejscach, w których powinny znajdować się ekwiwalenty wyrazu języka wyjściowego. Studenci mają za zadanie wypełnić luki, korzystając ze słowników jedno- i dwujęzycznych. Cel: wyrabianie u studentów nawyku kontrolnego sprawdzania wybranych odpowiedników w jednojęzycznym słowniku języka docelowego.

Ćwiczenie 4: Nauczyciel rozdaje karty pracy z obrazem ogólnie znanego przedmiotu lub obiektu (załącznik 4). Zadaniem studentów jest nazwanie poszczególnych części tego przedmiotu lub obiektu i znalezienie w słowniku dwujęzycznym odpowiedników w języku docelowym. Cel: kształtowanie umiejętności korzystania ze słownika dwujęzycznego.

Zaproponowane powyżej ćwiczenia dotyczące pracy ze słownikami zostały wybrane ze względu na ich charakter poznawczy. Studenci w praktyce poznają leksykograficzne zasady budowy słowników (układ haseł, struktura artykułu hasłowego, różnego rodzaju informacje zawarte w artykule hasłowym, np. informacje gramatyczne czy etymologiczne, kwantyfikatory, hasła odsyłaczowe). Dzięki zdobytej w ten sposób wiedzy rozwijają oni sprawność szybkiego i efektywnego korzystania ze słowników. Drugim istotnym kryterium wyboru był cel dydaktyczny, a mianowicie ćwiczenia uczą analizowania danych i krytycznego podejścia do informacji prezentowanych w słownikach dwujęzycznych oraz pozwalają wyrobić nawyk weryfikowania pozyskanych informacji w słowniku jednojęzycznym. 


\section{Teksty paralelne}

Badania nad tekstami paralelnymi w przekładoznawstwie zapoczątkowali Jean-Paul Vinay i Jean Darbelnet, autorzy Stylistique compareée du français et de l'anglais (1958) (por. Wilss 1996: 156, Nord 2002: 11). Dziś analiza tekstów paralelnych stanowi uznaną już metodę pracy zarówno $\mathrm{w}$ praktyce, jak i w dydaktyce przekładu, ponieważ w łatwy sposób pozwala ustalić różnice językowe i kulturowe dotyczące konwencji tekstowych w języku wyjściowym i docelowym. Pozwala także wykonać tłumaczenie, które pod względem językowym i kulturowym spełnia oczekiwania odbiorców, posługujących się językiem docelowym (por. Kautz 2002: 97, Göpferig 2006: 184).

Tekst paralelny to „tekst w języku docelowym, należący do tego samego gatunku co tekst wyjściowy i/lub traktujący o tej samej problematyce, z którego tłumacz może wynotować terminy, wyrażenia i wiadomości tematyczne, których potrzebuje, aby dokonać tłumaczenia" (Delisle i in. 2006: 97). Przytoczona definicja zawiera jeszcze jeden istotny powód uzasadniający wykorzystanie tego rodzaju tekstów zarówno w praktyce, jak i w nauczaniu przekładu. Otóż teksty paralelne są dla tłumacza nieocenionym źródłem terminologii, kolokacji oraz środków stylistycznych stosowanych w określonych gatunkach tekstów jak i wiarygodnym źródłem wiedzy.

Praca $\mathrm{z}$ tekstami paralelnymi na zajęciach tłumaczeniowych polega przede wszystkim na opisywaniu i porównywaniu wzorców językowych zawartych w tekstach języka wyjściowego i docelowego. Najlepsze efekty przynosi praca $\mathrm{z}$ tekstami silnie skonwencjonalizowanymi, czyli takimi, w których obowiązują pewne normy stylistyczne. Należą do nich np. komunikaty meteorologiczne, streszczenia artykułów naukowych, ulotki informacyjne dołączane lekarstw, instrukcje obsługi, hasła encyklopedyczne (por. Kautz 2002: 98-99). Odnosi się to również do tekstów specjalistycznych, np. z dziedziny prawa (akty prawne, wyroki itp.).

Podsumowując powyższe uwagi teoretyczne, należy stwierdzić, iż celem rozwijania umiejętności korzystania $\mathrm{z}$ tekstów paralelnych powinno być uświadomienie studentom, że kompetencja ta pozwala na podjęcie właściwej decyzji na płaszczyźnie translatorskiej i na wykonanie tłumaczenia zgodnego z normami obowiązującymi dla określonego gatunku tekstu w języku docelowym, gdyż teksty paralelne stanowią „prawdziwe wzorce tekstowe pod względem języka, stylu i konwencji" (Krzysztoforska-Weisswasser 1995: 18). 
Na zakończenie parę propozycji ćwiczeń z wykorzystaniem tekstów paralelnych ${ }^{3}$, które w praktyce pozwalają kształcić umiejętności pozyskiwania informacji z tego źródła.

Ćwiczenie 1: Nauczyciel dzieli studentów na małe grupy. Połowa grup otrzymuje kartę pracy z przepisem kulinarnym do przetłumaczenia oraz dwa lub trzy przepisy kulinarne w języku docelowym, w których zaznaczono elementy typowe dla tego gatunku tekstu. Druga połowa otrzymuje kartę pracy z innym przepisem kulinarnym, lecz wykonuje tłumaczenie bez pomocy tekstów paralelnych w języku docelowym. Po wykonaniu zadania grupy wymieniają się tłumaczeniami i oceniają ich jakość, wymieniając się przy tym swoimi doświadczeniami zebranymi w czasie pracy nad przekładem. Cel: uświadomienie studentom, że odbiorcy posługującemu się językiem docelowym tłumaczenie dokonane bez korzystania $\mathrm{z}$ tekstów paralelnych może wydawać się obce. Tym samym wykonany przekład nie będzie spełniać funkcji określonej w zleceniu.

Ćwiczenie 2: Nauczyciel rozdaje karty pracy z tekstem zawierającym luki i listą, na której w alfabetycznym porządku znajdują się zarówno wyrazy, które należy wstawić, jak i wyrazy, które są nietypowe dla danego gatunku tekstu (załącznik 5). Zadanie studentów polega na uzupełnieniu tekstu właściwymi wyrazami. Cel: uwrażliwienie na konwencje tekstowe.

Ćwiczenie 3: Nauczyciel rozdaje karty pracy zawierające kopie ulotek informacyjnych dołączonych do opakowania leków zarówno w języku wyjściowym, jak i docelowym. Należy wybrać taki lek, który jest popularny w obu kulturach, np. aspirynę. Studenci pracują w małych grupach i porównują otrzymane teksty (strukturę tekstów, słownictwo, rodzaje zdań). Wyniki pracy, tj. ustalone podobieństwa i różnice, omawia się wspólnie na forum. Cel: uświadomienie studentom podobieństw i różnic językowych i strukturalnych analogicznych gatunków tekstów funkcjonujących w dwóch kulturach.

Zaprezentowane powyżej ćwiczenia zostały wybrane w szczególności ze względu na ich charakter poznawczy. Pozwalają one bowiem pokazać studentom w praktyce, że tłumacz, opierając się jedynie na nawet najlepszych słownikach dwujęzycznych czy jednojęzycznych, nie jest w stanie wykonać tłumaczenia, które będzie spełniało określoną w zleceniu funkcję oraz będzie odpowiadało oczekiwaniom odbiorców pod względem językowym i kulturowym. Tłumacz musi również umieć wykorzystywać teksty paralelne będące doskonałym źródłem konwencji językowych obowiązujących dla określonych gatunków tekstów.

\footnotetext{
3 Ćwiczenia pochodzą z publikacji Ulricha Kautza (2002: 196-197, 228-237).
} 


\section{Uwagi końcowe}

Obecnie wykonywanie zawodu tłumacza wiąże się nie tylko z kompetencją tłumaczenia, lecz także $\mathrm{z}$ wieloma innymi umiejętnościami, które są wręcz niezbędne do funkcjonowania na dzisiejszym rynku pracy. Do umiejętności tych niewątpliwie należy zdolność efektywnego wyszukiwania informacji i krytycznego podejścia do różnych źródeł informacji. Z uwagi to, że tłumacz większość czasu pracy musi poświęcić na poszerzanie zasobów swojej wiedzy, rozwijanie tej umiejętności powinno stanowić integralny komponent nauczania przekładu. Praktyka pokazuje, że mimo ogromnego postępu technicznego słowniki i teksty paralelne, zarówno w tradycyjnej wersji drukowanej, jak i w wersji elektronicznej, nadal stanowią główne wyposażenie warsztatu pracy tłumacza. Dlatego też na zajęciach przekładowych warto nauczyć studentów efektywnego korzystania $\mathrm{z}$ tych narzędzi. W odniesieniu do słowników należy uświadomić studentom, że są one dobrym, lecz nie idealnym źródłem informacji, że korzystanie zwłaszcza ze słowników dwujęzycznych wymaga ostrożności i rozwagi i że tłumacz powinien mieć nawyk weryfikowania informacji pozyskanych ze słownika dwujęzycznego w słowniku jednojęzycznym. Ćwiczenia z tekstami paralelnymi mają natomiast na celu uwrażliwienie na konwencje tekstowe obowiązujące dla analogicznych gatunków tekstów w języku docelowym i wykształcenie umiejętności ich wykorzystania do wykonania profesjonalnego tłumaczenia. 


\section{Załącznik 1}
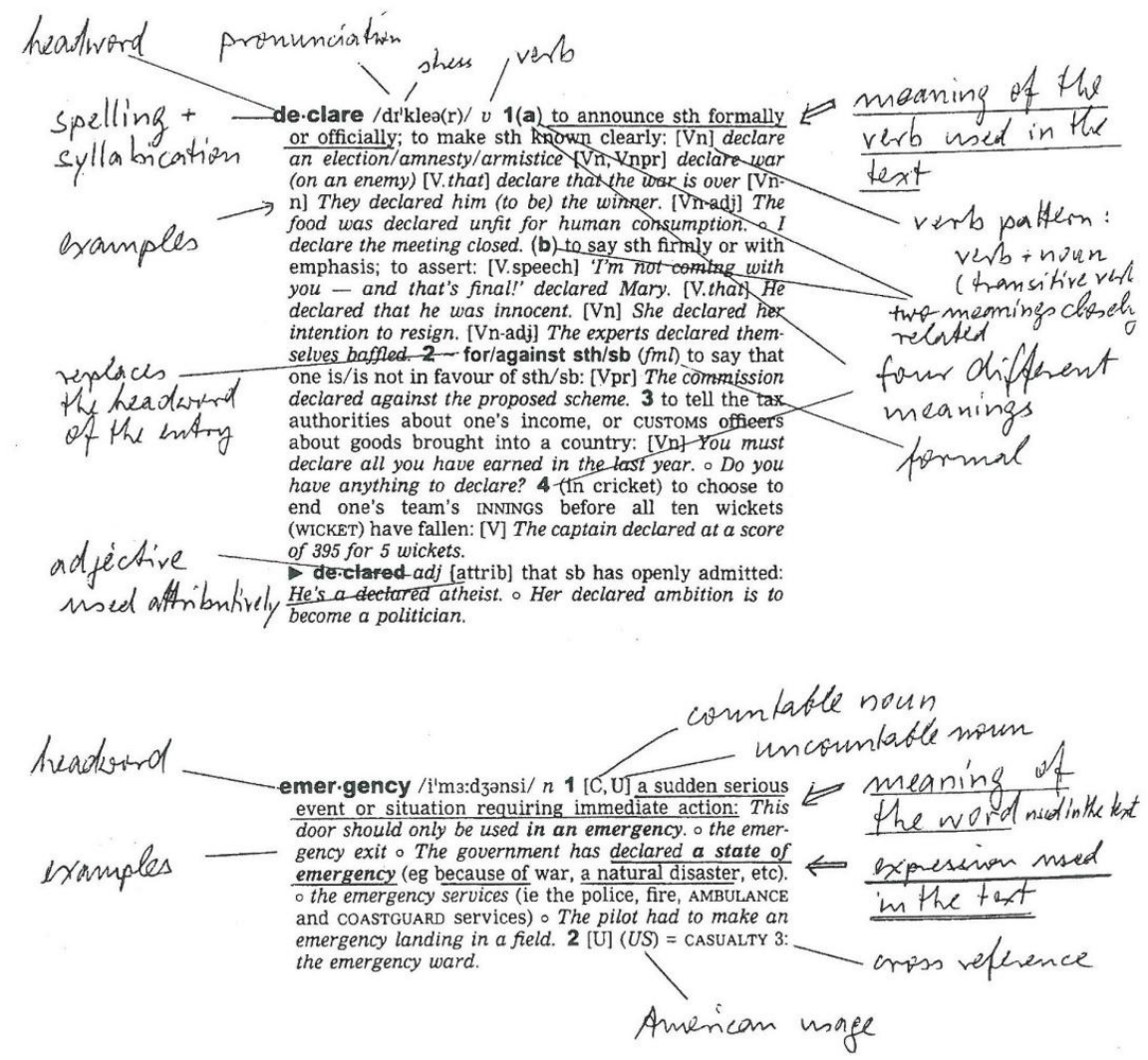

\section{Załącznik 2}

Deax exhonties,

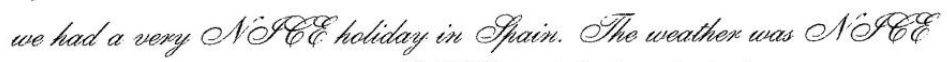

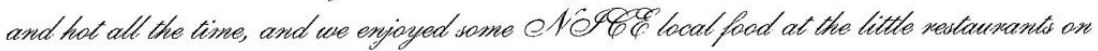
the seafront. Ifane bought herself an extremely eV OfCL blue drews - the did lady in the

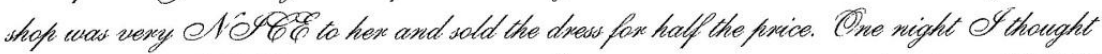

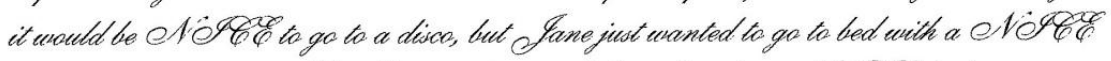

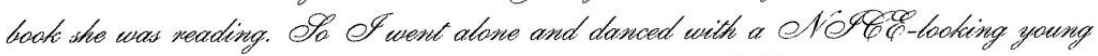

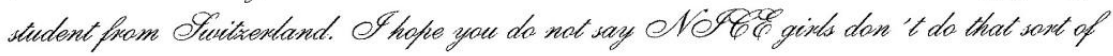
thing. 


\section{Załącznik 3}

1. Das Deutsche Rote Kreuz schickt eine Wasseraufbereitungsanlage. 120.000 Liter sauberes Wasser produziert die Anlage.

2. Gründer und erster Direktor des Mainzer Botanischen Gartens war der Botaniker Prof. Dr. Wilhelm Troll (1897-1978). Bei der Anlage des Gartens wurde er durch Max Top (1895-1986), den ersten Technischen Leiter des Gartens, unterstützt.

3. Mit der Anlage in Aktien werden Sie Eigentümer eines Unternehmens. Die angelegte Summe ist eng verknüpft mit dem Schicksaal dieser Firma. Firmen können Insolvenz gehen, oder auch nur schlecht im Vergleich zu anderen Unternehmen im Markt abschneiden. Das alles ist für einen kleinen Aktionär, der seine Informationen aus der Presse erhält kaum absehbar.

4. Die Italiener wollen die Insel Farwa nahe der Grenze zu Tunesien touristisch erschließen und den größten Hotelkomplex des Landes errichten - eine Anlage für 3800 Urlauber.

5. Liebe Vereinsmitglieder, am 18.4.2012 lädt der Vorstand des Vereines zur 5. Mitgliederversammlung ein.

Eine detaillierte Einladung und die Tagesordnung erhalten Sie in der Anlage. Wir freuen uns auf Ihr Erscheinen und Ihre Fragen.

Mit freundlichem Gruß

6. Das Wort Anlage bezeichnet eine natürliche Fähigkeit zu einer Sache. Er hat Anlage zur Musik, heißt eben so viel, als er besitzt die Eigenschaften, wodurch er fähig wird, in der Kunst starke Fortschritte zu machen.

\section{Załącznik 4}

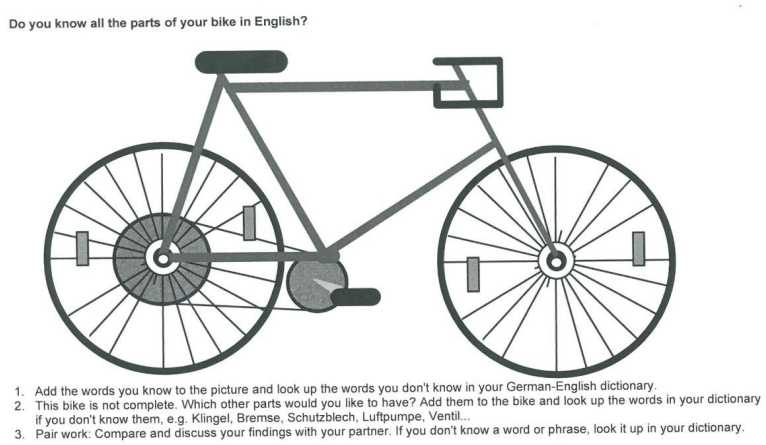




\section{Załącznik 5}

In runden Klammern Vorschläge für Lücken, in eckigen Klammern Vorschläge für Ausdrücke, die bei dieser Textsorte (= nichtwissenschaftlicher Text, Untersorte Zeitungstext, Gattung Feuilletontext) untypisch wären.

\section{Literatura}

Abstract of the European Quality Standard for Translation Services (EN15038), http://www.eurocom.at:8080/vmapplicants/docs/Abstract $\% 20$ of\%20Standard\%20EN15038_EN.pdf (dostęp: 20 lipca 2012 r.).

Co brzmi w trzcinie. Magazyn dla piszacych po polsku, nr 8, lipiec 2011, http:// ec.europa.eu/ translation/polish/magazine/documents/issue8_pl.pdf (dostęp: 20 lipca 2012 r.).

Delisle, J., i in., (red.), 2006, Terminologia tłumaczenia, Poznań.

Dzierżanowska, H., 1990, Przekład tekstów nieliterackich na przykładzie języ$k a$ angielskiego. Warszawa.

Eco, U., 2004, Imię róży, przekł. A. Szymanowski, Kraków.

ePolska. Plan działań na rzecz rozwoju społeczeństwa informacyjnego w Polsce na lata 2001-2006, 2001, http://kbn.icm.edu.pl/cele/epolska.doc (dostęp: 21 lipca 2012 r.).

European Master's in Translation, http://ec.europa.eu/dgs/translation/programmes/emt/key_ documents/emt_competences_translators_en.pdf (dostęp: 20 lipca 2012 r.).

Europejskie studia drugiego stopnia $w$ dziedzinie tłumaczeń, http://ec.europa. $\mathrm{eu} /$ dgs/trans-lation/programmes/emt/network/documents/emt_factsheet_pl.pdf (dostęp: 20 lipca 2012 r.).

Göpferich, S., 2006, „Paralleltexte”, [w:] Handbuch Translation, M. Snell-Hornby $\mathrm{i}$ in. (red.), Tübingen, s. 184-186.

Göpferich, S., 2008, Translationsprozessforschung. Stand - Methoden - Perspektiven, Tübingen.

Göpferich, S., 2009, „Vom Novizen zum Experten: Die Modellierung (der Entwicklung) translatorischer Kompetenz", [w:] Translatione via facienda. Festschrift für Christiane Nord zum 65. Geburtstag, G. Wotjak i in. (red.), Tübingen, s. 75-90.

Hansen, G., 2006, Erfolgreich übersetzen. Entdecken und Beheben von Störquellen, Tübingen.

Hejwowski, K., 2004, Kognitywno-komunikacyjna teoria przekładu, Warszawa. 
Hönig, H.G., 2006, „Textverstehen und Recherchieren”, [w:] Handbuch Translation, M. Snell-Hornby i in. (red.), Tübingen, s. 160-164.

Kautz, U., 2002, Handbuch Didaktik des Übersetzens und Dolmetschens, München.

Kielar, B.Z., 2000, „O tłumaczeniu tekstów specjalistycznych”, [w:] Problemy komunikacji międzykulturowej. Linguistyka translatoryka, glottodydakty$k a$, B.Z. Kielar i in. (red.), Warszawa, s. 235-246.

Koller, W., 2011, Einführung in die Übersetzungswissenschaft, Tübingen.

Kościałkowska-Okońska, E., 2007, „Kształtowanie kompetencji tłumaczeniowej jako wyzwanie dydaktyczne", [w:] Warsztaty Translatorskiel Workshop on Translation IV, R. Sokoloski i in. (red.), Lublin-Ottawa, s. 217-231.

Krzysztoforska-Weisswasser, Z., 1995, „Wykorzystanie tekstów paralelnych przy tlumaczeniu wyroków w procesie cywilnym”, [w:] Lingua Legis, 2, s. $18-20$.

Materialien zu dem Themenbereich Arbeit mit dem Wörterbuch, http://www. standardsicherung.schulministerium.nrw.de/cms/upload/ue-englisch/ weitere_materialien/e-umgangwbuch.pdf (dostęp: 22 lipca 2012 r.).

Nord, B., 2002, Hilfsmittel beim Übersetzen. Eine empirische Studie zum Rechercheverhalten professioneller Übersetzer, Frankfurt am Main.

Piotrowska, M., 2007, Proces decyzyjny tłumacza. Podstawy metodologii nauczania przekładu pisemnego, Warszawa.

Snell-Hornby, M., 2006, „Wörterbücher”, [w:] Handbuch Translation, M. Snell-Hornby i in. (red.), Tübingen, s. 181-184.

Stolze, R., 1988, „Zum Gebrauch von Wörterbüchern beim Übersetzen”, [w:] TEXTconTEXT 3.1, 43-62.

Wilss, W., 1996, Übersetzungsunterricht: Eine Einführung. Begriffliche Grundlagen und methodische Orientierungen, Tübingen.

Worbs, Erika, 1997, „Plädoyer für das zweisprachige Wörterbuch als Hilfsmittel des Translators", http://www.fb06.uni-mainz.de/inst/is/polnisch/texte/plaedoyer.pdf (dostęp: 22 lipca 2012 r.), s. 1-11.

\section{Developing information mining competence in translation teaching exemplified by working with dictionaries and parallel texts}

Summary

Information mining competence is one of the six professional competences of translators worked out by a group of experts appointed in 2007 by the Directorate- 
General for Translation (DGT) of the European Commission within the project of creating the European Master's in Translation (EMT) network. The six skills are as follows: translation service provision competence, language competence, intercultural competence, information mining competence, thematic competence and technological competence (mastery of tools). Information mining competence is understood as an ability to search for information with a critical attitude to various information sources. The reason why professional translators need this skill today more than ever is because of efficient time management, because of the mass of information and a wide range of source types from which information can be gathered (dictionaries, glossaries, thesauri, parallel texts, encyclopedias, CAT tools and other electronic media, etc.). The need was recognized also by the European Committee for Standards which in 2006 released the specification EN 15038 that defines translation quality and normalizes procedures and translation processes for delivering language services. There are six competences in the specification which translators should at least have, namely, translating competence, linguistic and textual competence in the source language and the target language, research competence and information acquisition and processing, cultural competence and technical competence. However, developing information mining competence remains in the background of teaching translation or is completely omitted as a simple and obvious skill. Translation practice shows that the ability to effectively search for information with a critical attitude to various information sources should be an absolutely necessary component in the training of professional translators. That is why the present paper focuses on developing information mining competence and suggests some examples of exercises how to use dictionaries and parallel texts effectively and how to extract and process relevant information for translation tasks. 